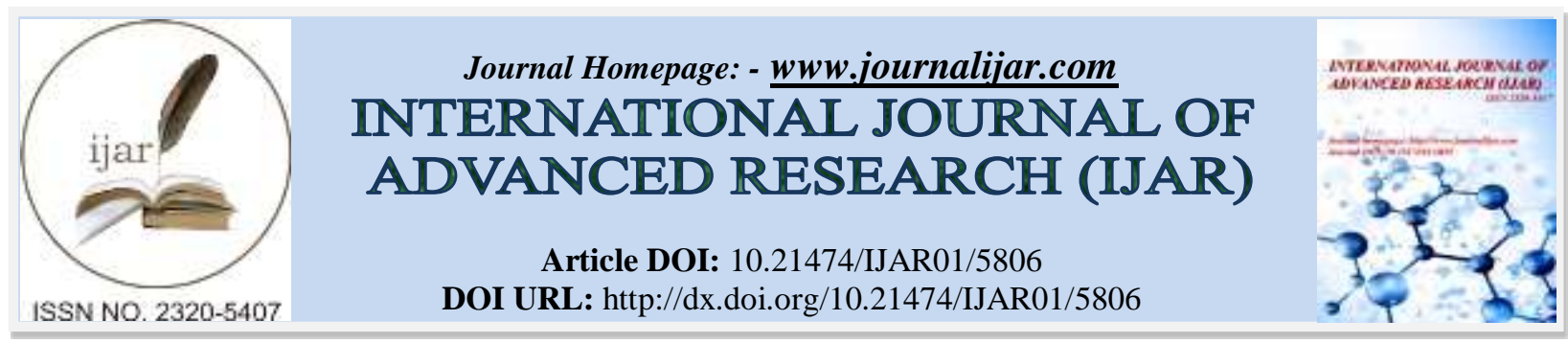

RESEARCH ARTICLE

\title{
EPIDEMIC AND PANDEMIC EVENTS PREPAREDNESS IN MINISTRY OF HEALTH HOSPITALS, JEDDAH, 2017, A CROSS SECTIONAL STUDY.
}

\author{
Saeed M. Algarni, Hani A. Almalki and Rajaa M. Al-Raddadi. \\ Ministry of Health, Saudi Arabia
}

\section{Manuscript Info}

Manuscript History

Received: 08 September 2017

Final Accepted: 10 October 2017

Published: November 2017

\begin{abstract}
Background: Recently various epidemic and pandemic events have been occurred worldwide with negative impacts on health, economic and social aspects of life. Health care workers are at high risk for acquiring any epidemic virus, which can threaten their lives.

Objective: This study was conducted to assess concerns, perceived impacts, and HCWs preparedness for epidemic and pandemic events in MOH hospitals in Jeddah for 2017

Methods: A structured self-administered questionnaire was prepared to assess the concerns, perceived impacts, and $\mathrm{HCW}$ preparedness for epidemic and pandemic events in MOH hospitals.

Results: The majority realized that their profession incurred them the risk of exposure to infection, occupational exposure to infection was accepted as part of professional duty in $>60 \%$ of our sampled HCWs. The minority of HCWs would dismiss to keep taking care of their patients and would think to quit their work during epidemic and pandemic events.

Conclusions: There is a need to enhance human resources capacities through psychosocial support and comprehensive training programs for epidemic and pandemic preparedness and response.
\end{abstract}

Copy Right, IJAR, 2017,. All rights reserved.

\section{Introduction:-}

Epidemic and pandemic events are considered one of the significant challenges which pose threats to health security globally. In recent years, countries worldwide have been exposed to various epidemic and pandemic events, disrupting the economic, social, and health aspects of life. Emerging infectious diseases have been growing substantially, particularly H1N1, H5N1, H7N9, and the Middle East respiratory syndrome (MERS-CoV) ${ }^{(1)}$. In the past century, four influenza pandemics occurred. The first pandemic incident in the twenty-first century appeared in 2009 in Mexico, where the novel strain H1N1 emerged ${ }^{(2)}$. It spread rapidly over the world within a few weeks.

Recently, the MERS coronavirus (MERS-CoV) emerged as an infectious disease first reported in 2012 in Saudi Arabia ${ }^{(3)}$. An increased number of MERS-CoV cases occurred in one hospital in Jeddah, where $20.9 \%$ of the cases were in medical staff and $97.3 \%$ occurred due to contact with healthcare facilities ${ }^{(4)}$. A multi-facility outbreak of 38 cases of MERS-CoV infection was reported in Taif, 13 of which occurred among healthcare workers (HCWs) ${ }^{(5)}$. All these emphasize the unpreparedness for epidemic events in the healthcare system. 
HCWs are at high risk for contracting any epidemic virus, which can threaten their lives. During the earlier epidemic waves, HCWs experienced extreme stress, lifestyle effects, and, to a long extent, psychological sequelae ${ }^{(6)}$, which were apparent in the most recent outbreaks of MERS-CoV, Ebola, and SARS ${ }^{(7-9)}$. Furthermore, social consequences could result, such as social avoidance, anxiety of family members, and loss of support from the employer.

Failure to share accurate, transparent, and timely information earlier during an outbreak increased anxiety among HCWs and presented a challenge in outbreak control management ${ }^{(10)}$. Therefore, to effectively manage future disease outbreaks, it is necessary to determine influencing factors of personal and social aspects ${ }^{(11)}$. Moreover, assessment of situation preparedness at the individual and institutional levels is crucial.

Epidemic and pandemic events were associated with a noteworthy increment in absenteeism among HCWs. In Hong Kong, a study showed an increased number of HCW absenteeism during the $2009 \mathrm{H} 1 \mathrm{~N} 1$ pandemic ${ }^{(12)}$. A similar study on Australian emergency department nurses and medicine staff during the 2009 influenza pandemic reported high rates of staff absenteeism, averaging 3.73 days ${ }^{(13)}$. These results reveal the principle of contingency workforce and surge capacity planning as a critical part of institutional pandemic planning.

Training drills are also crucial to improve HCW performance for preparedness during epidemic and pandemic events. Immersive simulation education can be used to assess the experiences of participants. In one study, most participants acquired more knowledge after training exercises ${ }^{(14)}$. Infection prevention and mass vaccination training in the US recommended more pre-event training to achieve effective points of dispensing (POD) ${ }^{(15-16)}$. Different modalities of the training program were used, and various preparedness aspects were implemented. Findings showed a significant improvement associated with these training programs ${ }^{(17-20)}$. We conducted this study to assess concerns, perceived impacts, and HCWs preparedness for epidemic and pandemic events in MOH hospitals in Jeddah for 2017.

\section{Subjects and Methods:- \\ Study setting:-}

This study was conducted in MOH hospitals in Jeddah, which is the main port of entry to Makkah and is regarded as one of the largest places of mass gathering in the world. The hospitals included five general adult hospitals and two paediatric hospitals.

\section{Study design and Population:-}

This descriptive cross-sectional survey was conducted from 1 June to end of August 2016 in Jeddah. The study population comprised all accessible HCWs who were working at the seven MOH hospitals in Jeddah, were direct clinical care providers (physicians, nurses, pharmacists, laboratory technicians, and other clinical support staff), and consented to participate.

\section{Sample size:-}

Sample size was calculated for an alpha of 0.05 , based on a $71.6 \%$ overall prevalence of perceived preparedness among HCWs, taken from a study conducted in Singapore in 2006 about concerns and preparedness for an avian influenza pandemic among HCWs ${ }^{(21)}$. The total population of the MOH hospitals in Jeddah was $8126 \mathrm{HCWs}$ ${ }^{(22)}$.The sample size was $305 \mathrm{HCWs}$, which was estimated using OpenEpi version 3.03a. We added 20\% of potential unresponsive participants.

\section{Sampling technique:-}

Sstratifiedd random sampling was conducted to select the study sample of HCWs from the different included hospitals. The stratification was according to the type of job titles, for instance, doctors, nurses, and clinical support staff. Subsequently, a random sample was included in each stratum using proportional allocation technique.

\section{Study tools:-}

A structured self-administered questionnaire was prepared to assess the concerns, perceived impacts, and HCW preparedness for epidemic and pandemic events in $\mathrm{MOH}$ hospitals. The questionnaire was adopted from an original survey of concerns and preparedness for an avian influenza pandemic in Singapore in $2006^{(21)}$, and was formulated according to our objective. It consisted of five sections, each including some questions. The five sections were independent variables, which were as follows:

1. Demographic data 
2. Work-related concerns of HCWs

3. Non-work-related concerns of HCWs

4. Perceived impact on the personal life and work of HCWs

5. HCW preparedness for epidemic and pandemic events

The dependent variable was the degree of HCW preparedness.

\section{Data collection technique:-}

We distributed questionnaires to the respondents who agreed to participate in the study after explaining the purpose of the survey and clarifying precautions about the questionnaire. The surveyed participants anonymously filled the self-administered questionnaires, which we collected afterwards.

\section{Data entry and statistical analysis:-}

After data collection, the data were revised, coded, and entered using statistical software IBM SPSS version 20. The given graphs were constructed using Microsoft Excel. All statistical analyses were performed using two-tailed tests and an alpha error of 0.05 . A $\mathrm{P}$ value $\leq 0.05$ was considered statistically significant. In descriptive statistics, Frequencies and percentages were used to describe the frequency of each category for categorical data. Mean with standard deviation was used to describe scale data.

\section{Pilot study:-}

A pilot study was conducted in one hospital to assure feasibility. Consequently, the study needed more human resources to assist in data collection.

\section{Ethical considerations:-}

This study was approved by the Ethics Review Committee No. (H-02-J-002) and date 4-4-1438 H .All participants provided written informed consent. All collected data were kept confidential and were not disclosed except for the study's purpose.

\section{Results:-}

\section{HCWs Demographic Characteristics:-}

Table 1 demonstrates that nearly samples were selected according to the weight of the population from different hospitals for representativeness. Response rate was $93.7 \%$. More than half of the sample population $(53.6 \%)$ were aged $<30$ years, while only $2.9 \%$ were $>50$ years. Moreover, $59.5 \%$ of the included HCWs were females, and $40 \%$ were males. Regarding marital status, most of the sample were married $(53.1 \%)$, while $40 \%$ comprised single staff. For educational level, $48.1 \%$ of the included HCWs had bachelor degree followed by $28.7 \%$ with diploma while those with post graduate degrees composed $23.2 \%$ of the sample. Considering the job title, $36.7 \%$ were nurses, followed by doctors (31.8) and laboratory staff (12.5\%), while other jobs constituted only about $18 \%$.

Table (1):- Socio-demographic characteristics of health care workers at MOH hospitals Jeddah, 2017

\begin{tabular}{|c|c|c|c|}
\hline \multicolumn{2}{|r|}{ Socio-demographic data } & No & $\%$ \\
\hline \multirow[t]{4}{*}{ Age in years } & $<30$ years & 184 & $53.6 \%$ \\
\hline & $30-$ & 109 & $31.8 \%$ \\
\hline & $40-$ & 40 & $11.7 \%$ \\
\hline & 50 years or more & 10 & $2.9 \%$ \\
\hline \multirow[t]{2}{*}{ Sex } & Male & 139 & $40.5 \%$ \\
\hline & Female & 204 & $59.5 \%$ \\
\hline \multirow[t]{4}{*}{ Marital status } & Single & 137 & $40.4 \%$ \\
\hline & Married & 180 & $53.1 \%$ \\
\hline & Divorced & 19 & $5.6 \%$ \\
\hline & Widow & 3 & $.9 \%$ \\
\hline \multirow[t]{4}{*}{ Educational level } & Diploma & 98 & $28.7 \%$ \\
\hline & Bachelor & 164 & $48.1 \%$ \\
\hline & Postgraduate master degree / equivalent & 43 & $12.6 \%$ \\
\hline & Postgraduate doctoral degree / equivalent & 36 & $10.6 \%$ \\
\hline \multirow[t]{2}{*}{ Job title } & Doctor & 109 & $31.8 \%$ \\
\hline & Nurse & 126 & $36.7 \%$ \\
\hline
\end{tabular}




\begin{tabular}{|l|c|c|}
\hline Laboratory personnel & 43 & $12.5 \%$ \\
\hline Pharmacist & 34 & $9.9 \%$ \\
\hline Others & 31 & $9.0 \%$ \\
\hline
\end{tabular}

Work related concerns regarding epidemic and pandemic events:-

Table 2 shows that among work-related concerns regarding epidemic and pandemic event items, the highest agreement rate was for feeling of risk exposure, which was recorded among $77.8 \%$ of HCWs, followed by being afraid of falling into the epidemic or pandemic attack (71.7\%) and accepting the risk of contracting infection as part of the job $(61.5 \%)$.

Non-work-related concerns regarding epidemic and pandemic event:-

Table 3 For non-work-related concerns regarding epidemic and pandemic event items, $73.8 \%$ of HCWs agreed on concern for their work colleagues, followed by agreement on the right of close people to worry for their health (73.5\%) and on being most concerned for their parents (71.4\%). The least agreed on items included the statement that 'people close to the staff would be worried as they may get infected by me' $(61.8 \%)$ and the high risk of infection for close people (64.7\%).

Table (2):- Descriptive of work related concerns regarding epidemic and pandemic event of health care workers at MOH hospitals, Jeddah, 2017

\begin{tabular}{|c|c|c|c|c|c|c|}
\hline \multirow{2}{*}{$\begin{array}{c}\text { Work related concerns regarding epidemic and } \\
\text { pandemic event }\end{array}$} & \multicolumn{2}{|c|}{ Disagreement } & \multicolumn{2}{|c|}{ Not sure } & \multicolumn{2}{|c|}{ Agreement } \\
\hline & No & $\%$ & No & $\%$ & No & $\%$ \\
\hline $\begin{array}{l}\text { 1-I feel that my job would put me at great exposure } \\
\text { risk }\end{array}$ & 50 & $14.6 \%$ & 26 & $7.6 \%$ & 267 & $77.8 \%$ \\
\hline $\begin{array}{l}\text { 2- I am afraid of falling ill in epidemic and pandemic } \\
\text { events }\end{array}$ & 52 & $15.2 \%$ & 45 & $13.1 \%$ & 246 & $71.7 \%$ \\
\hline $\begin{array}{l}\text { 3- I feel that I should not be looking after patients } \\
\text { with suspected infection during epidemic and } \\
\text { pandemic events }\end{array}$ & 177 & $51.6 \%$ & 75 & $21.9 \%$ & 91 & $26.5 \%$ \\
\hline $\begin{array}{l}\text { 4-I would accept that the risk of contracting } \\
\text { infectious disease in epidemic } \mathrm{c} \text { and pandemic events } \\
\text { is part of my job }\end{array}$ & 76 & $22.2 \%$ & 56 & $16.3 \%$ & 211 & $61.5 \%$ \\
\hline $\begin{array}{l}\text { 5-The risk I would be exposed to at work is not } \\
\text { acceptable }\end{array}$ & 119 & $34.7 \%$ & 81 & $23.6 \%$ & 143 & $41.7 \%$ \\
\hline $\begin{array}{l}\text { 6-I might look for another job or consider resigning } \\
\text { because of the risk of contracting infectious disease } \\
\text { in epidemic and pandemic events }\end{array}$ & 186 & $54.2 \%$ & 66 & $19.2 \%$ & 91 & $26.5 \%$ \\
\hline $\begin{array}{l}\text { 7-I would consider it acceptable if my colleagues } \\
\text { resign because of their fear of epidemic and } \\
\text { pandemic events }\end{array}$ & 120 & $35.0 \%$ & 78 & $22.7 \%$ & 145 & $42.3 \%$ \\
\hline $\begin{array}{l}\text { 8-I am confident that my employer would look after } \\
\text { my medical needs if I fall ill during epidemic and } \\
\text { pandemic events }\end{array}$ & 76 & $22.2 \%$ & 98 & $28.6 \%$ & 169 & $49.3 \%$ \\
\hline
\end{tabular}

Table (3):- Descriptive of non-work related concerns regarding epidemic and pandemic events of health care workers at MOH hospitals, Jeddah, 2017

\begin{tabular}{|l|c|c|c|c|c|c|}
\hline \multicolumn{1}{|c|}{$\begin{array}{c}\text { Non-work related concerns regarding } \\
\text { epidemic and pandemic events }\end{array}$} & \multicolumn{2}{|c|}{ Disagreement } & \multicolumn{2}{c|}{ Not sure } & \multicolumn{2}{c|}{ Agreement } \\
\cline { 2 - 6 } & No & \% & No & \% & No & \% \\
\hline $\begin{array}{l}\text { 9-People close to me would be at high risk of } \\
\text { getting infection because of my job }\end{array}$ & 60 & $17.5 \%$ & 61 & $17.8 \%$ & 222 & $64.7 \%$ \\
\hline $\begin{array}{l}\text { 10-I would be most concerned of my } \\
\text { spouse/partner }\end{array}$ & 27 & $7.9 \%$ & 83 & $24.2 \%$ & 233 & $67.9 \%$ \\
\hline 11-I would be most concerned of my parents & 31 & $9.0 \%$ & 63 & $18.4 \%$ & 249 & $72.6 \%$ \\
\hline 12-I would be most concerned of my children & 30 & $8.7 \%$ & 74 & $21.6 \%$ & 239 & $69.7 \%$ \\
\hline $\begin{array}{l}\text { 13-I would be most concerned of my close } \\
\text { friends }\end{array}$ & 32 & $9.3 \%$ & 66 & $19.2 \%$ & 245 & $71.4 \%$ \\
\hline
\end{tabular}




\begin{tabular}{|l|c|c|c|c|c|c|}
\hline $\begin{array}{l}\text { 14-I would be most concerned of my work } \\
\text { colleagues }\end{array}$ & 35 & $10.2 \%$ & 55 & $16.0 \%$ & 253 & $73.8 \%$ \\
\hline $\begin{array}{l}\text { 15-People close to me would be worried for } \\
\text { my health }\end{array}$ & 41 & $12.0 \%$ & 50 & $14.6 \%$ & 252 & $73.5 \%$ \\
\hline $\begin{array}{l}\text { 16-People close to me would be worried as } \\
\text { they may get infected by me }\end{array}$ & 60 & $17.5 \%$ & 71 & $20.7 \%$ & 212 & $61.8 \%$ \\
\hline
\end{tabular}

Perceived impact on personal life and work in epidemic and pandemic events:-

Table 4 clarifies that the agreement for all items was relatively low: 58.9\% of HCWs agreed that they have increased workload, while $57.4 \%$ agreed on feeling more stressed. Moreover, $44 \%$ were afraid of telling their families about the risk they were exposed to, and they told that they have to do work not normally done by them. Only $17.5 \%$ told that 'people would avoid my family members because of my job', while $25 \%$ avoided telling other people about the nature of their job.

\section{Preparedness for epidemic and pandemic events:-}

Table 5 demonstrates that about $75 \%$ of HCWs agreed on the presence of an infection control committee and infection control team at their hospitals, and $72 \%$ told that their hospitals informed them for vaccinations. Furthermore, about $60 \%$ told that they received training and adequate PPE and understood their benefits.

Table (4):- Descriptive of perceived impact on personal life and work in epidemic and pandemic events of health care workers at MOH hospitals, Jeddah, 2017

\begin{tabular}{|l|c|c|c|c|c|c|}
\hline $\begin{array}{l}\text { Perceived impact on personal life and work in epidemic } \\
\text { and pandemic events }\end{array}$ & \multicolumn{2}{|c|}{ Disagreement } & \multicolumn{2}{|c|}{ Not sure } & \multicolumn{2}{c|}{ Agreement } \\
\cline { 2 - 6 } & $\mathbf{N o}$ & $\mathbf{\%}$ & $\mathbf{N o}$ & $\mathbf{\%}$ & No & \% \\
\hline $\begin{array}{l}\text { 17-I would be afraid of telling my family about the risk I am } \\
\text { exposed to }\end{array}$ & 146 & $42.6 \%$ & 44 & $12.8 \%$ & 153 & $44.6 \%$ \\
\hline 18-People would avoid me because of my job & 185 & $53.9 \%$ & 74 & $21.6 \%$ & 84 & $24.5 \%$ \\
\hline $\begin{array}{l}\text { 19-People would avoid my family members because of my } \\
\text { job }\end{array}$ & 227 & $66.2 \%$ & 56 & $16.3 \%$ & 60 & $17.5 \%$ \\
\hline $\begin{array}{l}\text { 20-I would avoid telling other people about the nature of my } \\
\text { job }\end{array}$ & 211 & $61.5 \%$ & 45 & $13.1 \%$ & 87 & $25.4 \%$ \\
\hline $\begin{array}{l}\text { 21-There would be adequate staff at my workplace to handle } \\
\text { the increased demand }\end{array}$ & 119 & $34.7 \%$ & 89 & $25.9 \%$ & 135 & $39.4 \%$ \\
\hline $\begin{array}{l}\text { 22-There would be more conflict amongst colleagues at } \\
\text { work }\end{array}$ & 95 & $27.7 \%$ & 117 & $34.1 \%$ & 131 & $38.2 \%$ \\
\hline 23-I would feel more stressed at work & 105 & $30.6 \%$ & 41 & $12.0 \%$ & 197 & $57.4 \%$ \\
\hline 24-I would have an increase in workload & 78 & $22.7 \%$ & 63 & $18.4 \%$ & 202 & $58.9 \%$ \\
\hline 25-I would have to work overtime & 114 & $33.2 \%$ & 79 & $23.0 \%$ & 150 & $43.7 \%$ \\
\hline $\begin{array}{l}\text { 26-I would have to do work not normally } \\
\text { done by me }\end{array}$ & 113 & $32.9 \%$ & 78 & $22.7 \%$ & 152 & $44.3 \%$ \\
\hline
\end{tabular}

Table (5) a:- Descriptive of Preparedness for epidemic and pandemic events at MOH hospitals Jeddah, 2017 perceived by their health care workers

\begin{tabular}{|l|c|c|c|c|c|c|}
\hline \multicolumn{1}{|c|}{ Preparedness for epidemic and pandemic events } & \multicolumn{2}{|c|}{ Disagreement } & \multicolumn{2}{|c|}{ Not sure } & \multicolumn{2}{c|}{ Agreement } \\
\cline { 2 - 6 } & No & $\%$ & No & $\%$ & No & $\%$ \\
\hline $\begin{array}{l}\text { 27-There is an infection control committee in my } \\
\text { hospital }\end{array}$ & 39 & $11.4 \%$ & 47 & $13.7 \%$ & 257 & $74.9 \%$ \\
\hline $\begin{array}{l}\text { 28-I have received training for infection control at my } \\
\text { hospital }\end{array}$ & 94 & $27.4 \%$ & 37 & $10.8 \%$ & 212 & $61.8 \%$ \\
\hline $\begin{array}{l}\text { 29-I received adequate personal protective equipment } \\
\text { training }\end{array}$ & 76 & $22.2 \%$ & 45 & $13.1 \%$ & 222 & $64.7 \%$ \\
\hline $\begin{array}{l}\text { 30-I have someone to turn to if unsure of use of } \\
\text { personal protective equipment }\end{array}$ & 65 & $19.0 \%$ & 66 & $19.2 \%$ & 212 & $61.8 \%$ \\
\hline $\begin{array}{l}\text { 31-I have been recommended by my hospital to } \\
\text { receive the required vaccinations }\end{array}$ & 43 & $12.5 \%$ & 50 & $14.6 \%$ & 250 & $72.9 \%$ \\
\hline 32-There is infection control staff in my hospital & 26 & $7.6 \%$ & 56 & $16.3 \%$ & 261 & $76.1 \%$ \\
\hline
\end{tabular}




\begin{tabular}{|l|c|c|c|c|c|c|}
\hline $\begin{array}{l}\text { 33-My hospital has a preparedness plan for epidemic } \\
\text { and pandemic events }\end{array}$ & 41 & $12.0 \%$ & 132 & $38.5 \%$ & 170 & $49.6 \%$ \\
\hline $\begin{array}{l}\text { 34-My hospital has informed me of their epidemic } \\
\text { and pandemic events preparedness plan }\end{array}$ & 89 & $25.9 \%$ & 92 & $26.8 \%$ & 162 & $47.2 \%$ \\
\hline $\begin{array}{l}\text { 35-My hospital is prepared for epidemic and } \\
\text { pandemic events }\end{array}$ & 69 & $20.1 \%$ & 114 & $33.2 \%$ & 160 & $46.6 \%$ \\
\hline $\begin{array}{l}\text { 36-I have seen the plan to combat epidemic and } \\
\text { pandemic events in my hospital }\end{array}$ & 116 & $33.8 \%$ & 103 & $30.0 \%$ & 124 & $36.2 \%$ \\
\hline $\begin{array}{l}\text { 37-I am personally prepared for epidemic and } \\
\text { pandemic events }\end{array}$ & 111 & $32.4 \%$ & 87 & $25.4 \%$ & 145 & $42.3 \%$ \\
\hline
\end{tabular}

\section{Discussion:-}

Concerns, perceived impacts, and HCW preparedness for epidemic and pandemic events:-

In this study, most HCWs perceived that their job might endanger them and they may become ill. This is analogous to previous studies where the respondent staff felt at risk of contracting the infection at workplaces and had a sense of potential sickness during work ${ }^{(23-25)}$.

Although the majority realized that their profession incurred them the risk of exposure to infection, occupational exposure to infection was accepted as part of professional duty in $>60 \%$ of our sampled HCWs. Besides increased apprehension of HCWs to contracting infection, the minority of HCWs would dismiss to keep taking care of their patients and would think to quit their work during epidemic and pandemic events. These findings are consistent with previous studies conducted in Singapore, Egypt, and Indonesia ${ }^{(23,24,26)}$.

Our study showed that those with paramedical jobs had higher work concern than physicians and nurses. The low level of concern among physicians could be attributed to their level of knowledge, continued medical education for case management, scientific dependability, and clinical training compared with other HCWs, along with possible previous experience of similar events. Furthermore, marital status contributed to the increase in HCWs' concern.

Since the emergence of MERS-CoV, $31 \%$ of reported cases have been related to healthcare facilities, $19.6 \%$ of which have been reported in HCWs ${ }^{(27)}$. The increased number of affected HCWs has made their colleagues increasingly concerned about them. Besides, it was noted that HCWs were concerned for their family members and vice versa. This fits with the findings of other studies ${ }^{(23,26,28)}$.

Excess workload and exhausted work could be two factors which troubled more than half of the HCWs in our study. This was more obvious in a similar study conducted in Egypt, the rate of which was almost $90 \%{ }^{(23)}$.

During the pandemic and epidemic events that had occurred, social ostracism experienced by HCWs and their family was a prominent finding in previous studies, including a study conducted in Singapore in 2006 (63.5\% and $51.9 \%$, respectively) ${ }^{(21)}$, another study in $2007(57.1 \% \text { and } 46.4 \%)^{(24)}$, and a study in Egypt during the H1N1 pandemic in $2009(52.8 \% \text { and } 30.6 \%)^{(23)}$. However, our study revealed little concern on social ostracism among HCWs and their family regarding epidemic and pandemic events (24.5\% and $17.5 \%$, respectively), which is identical to the results of a study on avian influenza in South Jakarta ${ }^{(26)}$.

During the early outbreak of MERS-CoV, some secondary and tertiary hospitals in Saudi Arabia were overwhelmed and disrupted. This was, to some extent, due to breaks in infection control practices of the hospitals combined with unpreparedness of HCWs, worsened by insufficient PPE and lack of preparedness training ${ }^{, 29)}$.

On average, we found that most HCWs were aware about the presence of infection control committees and infection control staff in their hospital. Approximately more than two-thirds of the participants commented that they were recommended to take the required vaccination; this high proportion was the result of Saudi MOH's mandate that all HCWs should receive annual influenza vaccination ${ }^{(30)}$. Even though these results differ from some earlier studies, the results of one study in 29 European Union countries indicated that most European countries recommend influenza vaccination. However, HCW vaccination was still low. Our results are consistent with those in the US in 2014-2015, whereas vaccination coverage was $96.0 \%$ among HCWs working in healthcare facilities where 
vaccination was mandated ${ }^{(31)}$. Additionally, there is evidence to suggest that mandatory influenza vaccination policies could increase influenza vaccination coverage ${ }^{(32-34)}$.

The WHO has provided a framework of preparedness plans to ensure that countries worldwide are effectively prepared to respond to pandemic influenza. Approximately 103 countries currently do not have influenza pandemic preparedness plans, or these plans are not publicly available. Only 11 countries have revised and disseminated their national pandemic preparedness plans after $2014{ }^{35-36}$. Saudi Arabia published their pandemic preparedness plan before 2009, with no update so far. These were consistent with our results showing insufficient information about an epidemic and pandemic preparedness plan, wherein less than half of HCWs were not aware whether their hospital had a pandemic preparedness plan. However, these findings are contrary to studies in Singapore and Egypt that reported high values in both institutional and personal preparedness ${ }^{(23-24)}$. A study in Indonesia had findings similar with our findings ${ }^{(26)}$.

\section{Conclusion:-}

Based on our findings, the majority of HCWs have some concerns about epidemic and pandemic events. In addition, their poorly preparedness for managing these events in their hospitals. We suggest to enhance human resources capacities through psychosocial support and comprehensive training programs for epidemic and pandemic preparedness and response.

\section{Refrences:-}

1. Otter JA, Donskey C, Yezli S, Douthwaite S, Goldenberg SD, Weber DJ. Transmission of SARS and MERS coronaviruses and influenza virus in healthcare settings: The possible role of dry surface contamination. Vol. 92, Journal of Hospital Infection. 2016. p. 235-50.

2. Fineberg H V. Pandemic Preparedness and Response - Lessons from the H1N1 Influenza of 2009. N Engl J Med [Internet]. 2014;370(14):1335-42. Available from: http://www.nejm.org/doi/10.1056/NEJMra1208802

3. Assiri A, McGeer A, Perl TM, Price CS, Al Rabeeah AA, Cummings DAT, et al. Hospital Outbreak of Middle East Respiratory Syndrome Coronavirus. N Engl J Med [Internet]. 2013;369(5):407-16. Available from: http://www.nejm.org/doi/10.1056/NEJMoa1306742

4. Oboho IK, Tomezyk SM, Al-Asmari AM, Banjar AA, Al-Mugti H, Aloraini MS, et al. 2014 MERS-CoV Outbreak in Jeddah - A Link to Health Care Facilities. N Engl J Med [Internet]. 2015;372(9):846-54. Available from: http://www.nejm.org/doi/10.1056/NEJMoa1408636

5. Assiri A, Abedi GR, Bin Saeed AA, Abdalla MA, Al-Masry M, Choudhry AJ, et al. Multifacility outbreak of middle east respiratory syndrome in Taif, saudi Arabia. Emerg Infect Dis. 2016;22(1):32-40.

6. Koh D, Lim MK, Chia SE, Ko SM, Qian F, Ng V, et al. Risk perception and impact of Severe Acute Respiratory Syndrome (SARS) on work and personal lives of healthcare workers in Singapore: what can we learn? Med Care. 2005;43(7):676-82.

7. Wu P, Fang Y, Guan Z, Fan B, Kong J, Yao Z, et al. The psychological impact of the SARS epidemic on hospital employees in China: Exposure, risk perception, and altruistic acceptance of risk. Can J Psychiatry. 2009;54(5):302-11.

8. Ji D, Ji Y-J, Duan X-Z, Li W-G, Sun Z-Q, Song X-A, et al. Prevalence of psychological symptoms among Ebola survivors and healthcare workers during the 2014-2015 Ebola outbreak in Sierra Leone: a cross-sectional study. Oncotarget [Internet]. 2017;8(8):12784-91. Available from: http://www.ncbi.nlm.nih.gov/pubmed/28061463\%5Cnhttp://www.pubmedcentral.nih.gov/articlerender.fcgi?arti d=PMC5355054\%5Cnhttp://www.oncotarget.com/abstract/14498

9. Ro JS, Lee JS, Kang SC, Jung HM. Worry experienced during the 2015 Middle East Respiratory Syndrome (MERS) pandemic in Korea. PLoS One. 2017;12(3).

10. Hsu Y-C, Chen Y-L, Wei H-N, Yang Y-W, Chen Y-H. Risk and Outbreak Communication: Lessons from Taiwan's Experiences in the Post-SARS Era. Heal Secur [Internet]. 2017;15(2):165-9. Available from: http://online.liebertpub.com/doi/10.1089/hs.2016.0111

11. Sridhar S, Brouqui P, Fontaine J, Perivier I, Ruscassier P, Gautret P, et al. Risk perceptions of MSF healthcare workers on the recent Ebola epidemic in West Africa. New Microbes New Infect. 2016;12:61-8.

12. Ip DKM, Lau EHY, Tam YH, So HC, Cowling BJ, Kwok HKH. Increases in absenteeism among health care workers in Hong Kong during influenza epidemics, 2004-2009. BMC Infect Dis [Internet]. 2015;15(1):1-9. Available from: http://dx.doi.org/10.1186/s12879-015-1316-y

13. Considine J, Shaban RZ, Patrick J, Holzhauser K, Aitken P, Clark M, et al. Pandemic (H1N1) 2009 Influenza in 
Australia: Absenteeism and redeployment of emergency medicine and nursing staff. Emerg Med Australas [Internet]. 2011;23(5):615-23. Available from: http://www.ncbi.nlm.nih.gov/pubmed/21995477

14. Rega PP, Fink BN. Immersive Simulation Education: A Novel Approach to Pandemic Preparedness and Response. Public Health Nurs. 2014;31(2):167-74.

15. Rebmann T, Loux TM, Swick Z, Dolgin H, Reddick D, Wakefield M. Are US Jurisdictions Prepared to Dispense Medical Countermeasures Through Open Points of Dispensing? Findings from a National Study. Heal Secur. 2015;13(2):1-10.

16. Rebmann T, Loux TM, Zink TK, Swick Z, Wakefield M. Infection prevention and mass vaccination training for U.S. point of dispensing staff and volunteers: A national study. Am J Infect Control. 2015;43(3):222-7.

17. J.M. L, S. A. Computer simulation as a tool for assessing decision-making in pandemic influenza response training [Internet]. Vol. 14, Western Journal of Emergency Medicine. 2013. p. 236-42. Available from: http://escholarship.org/uc/item/1 nz370b6\%5Cnhttp://ovidsp.ovid.com/ovidweb.cgi?T=JS\&PAGE=reference\&D $=$ emed $15 \& N E W S=N \& A N=369130237$

18. Otto JL, Baliga P, Sanchez JL, Johns MC, Gray GC, Grieco J, et al. Training initiatives within the AFHSCGlobal Emerging Infections Surveillance and Response System: support for IHR (2005). BMC Public Health [Internet]. 2011;11 Suppl 2(SUPPL. 1):S5. Available from: http://www.scopus.com/inward/record.url?eid=2s2.0-79952541475\&partnerID=tZOtx3y1

19. Greci LS, Ramloll R, Hurst S, Garman K, Beedasy J, Pieper EB, et al. vTrain: A Novel Curriculum for Patient Surge Training in a Multi-User Virtual Environment (MUVE). Prehosp Disaster Med [Internet]. 2013;28(3):215-22. Available from: http://www.journals.cambridge.org/abstract_S1049023X13000083

20. Adini B, Goldberg A, Cohen R, Bar-Dayan Y. Impact of pandemic flu training on ability of medical personnel to recognize an index case of avian influenza. Eur J Public Health. 2012;22(2):169-73.

21. Cheong SK, Wong TY, Lee HY, Fong YT, Tan BY, Koh GC, et al. Concerns and preparedness for an avian influenza pandemic: a comparison between community hospital and tertiary hospital healthcare workers. Ind Health. 2007;45:653-61.

22. Saudi Ministry of Health. Statistical Book for the year 1436 [Internet]. Saudi Ministry of Health. 2015. p. 2849. Available from: http://www.moh.gov.sa/ministry/statistics/book/pages/default.aspx

23. El Gaafary MM, Abd Elaziz KM, Abdel-Rahman AG, Allam MF. Concerns, perceived impacts and preparedness of health care workers in a referral hospital in Egypt in facing influenza (H1N1) epidemic. J Prev Med Hyg. 2010;51(3):105-9.

24. Wong TY, Koh GC, Cheong SK, Lee HY, Fong YT, Sundram M, et al. Concerns, perceived impact and preparedness in an avian influenza pandemic--a comparative study between healthcare workers in primary and tertiary care. Ann Acad Med Singapore [Internet]. 2008;37(2):96-102. Available from: http://www.ncbi.nlm.nih.gov/pubmed/18327343

25. Abolfotouh MA, AlQarni AA, Al-Ghamdi SM, Salam M, Al-Assiri MH, Balkhy HH. An assessment of the level of concern among hospital-based health-care workers regarding MERS outbreaks in Saudi Arabia. BMC Infect Dis [Internet]. 2017;17(1):4. Available http://bmcinfectdis.biomedcentral.com/articles/10.1186/s12879-016-2096-8

26. Koh GCH, Abikusno N, Kwing CS, Yee WT, Kusumaratna R, Sundram M, et al. Avian influenza and south Jakarta primary healthcare workers: A controlled mixed-method study. Trop Med Int Heal. 2009;14(7):817-29.

27. Middle East respiratory syndrome coronavirus (MERS-CoV) WHO MERS-CoV Global Summary and Assessment of Risk Global summary. 2017 [cited 2017 Sep 8]; Available from: http://www.who.int/emergencies/mers-cov/risk-assessment-july-2017.pdf?ua=1

28. Jaakkimainen RL, Bondy SJ, Parkovnick M, Barnsley J. How infectious disease outbreaks affect communitybased primary care physicians: Comparing the SARS and H1N1 epidemics. Can Fam Physician. 2014;60(10):917-25.

29. Balkhy HH, Alenazi TH, Alshamrani MM, Baffoe-Bonnie H, Arabi Y, Hijazi R, et al. Description of a Hospital Outbreak of Middle East Respiratory Syndrome in a Large Tertiary Care Hospital in Saudi Arabia. Infect Control Hosp Epidemiol. 2016;37(10):1147-55.

30. Infection Prevention and Control Guidelines for Seasonal Influenza in Healthcare Setting Nov 2015.2015 [cited 2017 Sep 9];1-9. Available from: http://nebula.wsimg.com/db4dbae449d59be76ab542486bd6a584?AccessKeyId=56AE5CCCF0799F235A2E\&d isposition $=0$ \&alloworigin $=1$

31. Committee On Infectious D. Influenza Immunization for All Health Care Personnel: Keep It Mandatory. Pediatrics. 2015;136(4):809-18.

32. Bernstein HH, Starke JR. Policy statement--recommendation for mandatory influenza immunization of all 
health care personnel. Pediatrics [Internet]. 2010;126(4):809-15. Available from: http://www.ncbi.nlm.nih.gov/pubmed/20837587

33. Partnership Network | Strategic Partnership Portal [Internet]. [cited 2017 Sep 11]. Available from: https://extranet.who.int/spp/influenza

34. U.S. Department of Health and Human Services. Pandemic Influenza Plan - Update IV (December 2017) [Internet]. 2017 [cited 2017 Sep 11]. Available from: https://www.cdc.gov/flu/pandemic-resources/pdf/pan-flureport-2017v2.pdf 